\title{
Urgency of Internal Academic Quality Audit Policy at Higher Education
}

\author{
Dewi Nofrita ${ }^{1, a}$ Unifah Rosyidi1,b, Neti Karnati ${ }^{1, c}$ \\ 1Postgraduate Doctoral Program, State University of Jakarta, Jl Rawamangun Muka, East Jakarta, Indonesia \\ a dnsjafrigmail.com; b unifahr@gmail.com; c netiyupan@yahoo.com \\ ${ }^{*}$ Corresponding Author
}

How to Cite: Nofrita, D., Rosyidi, U ., Kamati, N. (2019).Urgency of Internal Academic Quality Audit Policyat Higher Education. International Journal for Educational and Vocational Studies, 1(4), 290-293

\section{ARTICLE HISTORY}

Received: 14 June 2019

Revised: 27 July2019

Accepted: 5 August 2019

\section{KEYWORDS}

Academic Quality Audit; Higher Education:

Policy;

\section{ABSTRACT}

Universities and education now require quality assurance to ensure the quality of education. The implementation of a quality assurance system that already underway requires an internal audit process to ensure the quality process continues. Internal audit has an important role in management. Internal quality assurance is carried out through a cycle of establishing, implementing, evaluating, controlling, and increasing the standards of higher education. "Internal quality audits are part of the cycle of the Internal Quality Assurance System (SPMI). A quality audit is not an assessment/assessment but rather a matching between the implementation and planning of an activity/program."

\section{INTRODUCTION}

The issuance of Permendikbud No. 49 of 2014 concerning the National Standards of Higher Education which must be implemented in all Universities in Indonesia, the ambon state Islamic institute developed the design of the QMS, which is a combination of ISO 9001: 2008, Study Program Accreditation Forms, Form of Institutional Accreditation and National Higher Education Standards (SN DIKTI). The design plan for implementing the quality assurance system at Ambon State Islamic Institute, in principle is a systematic process for continuous improvement in the quality of higher education that is manifested in the form of a cycle of quality assurance activities.

The cycle of quality assurance activities in the Ambon State Islamic Institute consists of components implemented in the PPEPP cycle model (Determination, Implementation, Evaluation, Control, Improvement) which will result in continuous improvement and development. An educational institution has a controlling factor, information and documentation are important and influence the quality of an educational institution.

The quality assurance of tertiary institutions in Indonesia was formally begun only in 2003, namely the issuance of higher education quality assurance guidelines. The factors that most spur the quality assurance movement are the necessity of universities to organize quality assurance, in addition to the demands of accountability and qualification of graduates (Olssen, 2004: 194). Quality assurance in higher education as a whole is very important because the goal of education is not only for academics but for the whole element (Adina, 2007: 2). But on the other hand, its presence can be based on other reasons such as dissatisfaction from education staff and students as well as pressure because of limited funds and most important is the demand for accountability to the institution (Tsui, 2002: 3).

The quality of higher education in Indonesia according to Achmad Anwar Abidin (2017: 87) is still inferior compared to our neighboring countries in the Southeast Asia region. That is why efforts to improve the quality of education are the concern of education experts and the government to make it happen. One of them is the academic quality assurance activities in higher education conducted by an internal audit in each unit and department.

The audit is carried out with standards to achieve the audit objectives that have been previously set. To maintain the quality of higher education, as well as the more complex quality assurance in the future there needs to be an internal academic quality audit policy planning related to the quality process at the College. The audit is designed to determine the suitability or incompatibility of elements of the quality system with the conditions set, to determine the 
effectiveness of achieving quality objectives that have been set, to provide audited opportunities to improve the quality system and to meet regulatory and requirements.

According to the Ministry of National Education (2010: 16) tertiary quality assurance is the process of planning, fulfilling, controlling and developing higher education standards consistently, so that internal and external stakeholders of higher education can obtain satisfaction with the performance and output of universities (Ahmad Sulaiman \& Udik Budi Wibowo, 2016: 28). Higher education undertakes efforts to improve the quality of higher education including through the implementation of an internal quality assurance system (Kadek Hengki Primayana, 2015: 7). Quality assurance in higher education is conducted to measure how effective academic policies are applied and how high the quality of graduates they produce, in addition, to increase competitiveness among universities, both at home and abroad.

\section{RESEARCH METHODS}

The qualitative approach is used to analyze the urgency of the internal academic quality audit policy at the Ambon State Islamic Institute. In this study, descriptive data were produced which aimed to provide a detailed description of the urgency of the internal academic quality audit policy in higher education, especially at the Ambon Islamic Institute.

Data is collected through interviews, observation, and documentation. In collecting data researchers used observation techniques, and information previously documented in the study. In qualitative research, researchers must be able to determine whether this research is a narrative or description and explained orally and in writing. The behavior of the subjects observed in the field is also part of the data in this study. The data analysis technique used is descriptive narrative. This technique according to Miles and Huberman is applied by using three methods, namely (1) Data reduction; (2) Presentation of data, and; (3) Closing.

\section{RESULTS AND DISCUSSION}

\section{a. Objectives of Internal Quality Audit}

The audit aims to see the suitability between the actual conditions and what is written in the document, the actual condition can be in the form of records or quality records or observations by looking at the procedure of someone doing his/her job according to what is written in the Work Procedure/Instruction. The audit also aims to see the potential for improvement (effectiveness \& efficiency) of a process.

An audit can also be used as a learning tool for auditors and auditees themselves because they can learn the process from other parts, and at the same time can transmit their knowledge to the part that is audited. especially this audit aims as a tool to monitor the implementation of the management system implemented by the company whether it is in accordance with what is desired or still needs to be improved, while mapping which department or section has good implementation and performance and which parts are not so good, so repair steps can be taken immediately.

In higher education that must implement various Dikti standards, the meaning of the main internal audit is internal audit aimed at continuously improving the quality of higher education in carrying out higher education in accordance with the vision of each audit. The purpose of an internal quality audit is not to find fault with audited parties, but to match the suitability of the higher education standards set by the PT with reality in the field, and is intended to look for opportunities for improving the internal quality of each study program.

This is to achieve quality in accordance with the expectations of all stakeholders of higher education in accordance with Law No.12 of 2012 concerning Higher Education, especially Article 52, paragraph 2 "Quality assurance as referred to in paragraph (1) is carried out through stipulation, implementation, evaluation, control and improvement of the standard of higher education. "And the evaluation referred to in Article 52 paragraph 2 of the Higher Education Law above can be done with a diagnostic evaluation, formative evaluation, summative evaluation and Internal Quality Audit (AMI).

Quality in the scope of education in higher education means that the functions, objectives, and standards determined and carried out in the scope of higher education are appropriate, fulfilling the requirements, expectations, and stakeholder satisfaction. Non-clean universities will be abandoned by stakeholders (Muhammad Khoiri, 2010: 208). The quality of graduates is related to the characteristics that are determined by the university and shows the readiness of graduates to dive in and work directly in the community and the world of work as expected by customers and stakeholders. In line with the explanation from Dikti (2003: 8) that it needs to be stated because stakeholders' evaluations are constantly evolving, quality assurance must also be adjusted to those developments in a sustainable manner. Based on the research results of Reddy Siram (2015: 54), it is revealed that universities need to pay attention to graduate quality assurance management because there are still many graduates who are absorbed in the workforce but not in accordance with the qualifications and educational background they occupy.

b. Policy urgency Internal academic quality audit in universities

According to Article 53 and Article 52 paragraph of the Higher Education Law, the Dikti SPM consists of an internal quality assurance system (SPMI) and an external quality assurance system (SPME) (Ristekdikti, 2010: 8; 2016: 7). Higher education quality assurance activities are carried out in a system called the university's internal quality assurance system that aims to ensure the quality of 
higher education held by each PT, through the implementation of the Tridharma of Higher Education, in order to realize the vision and meet the needs of the internal and external stakeholders of the university (Debby Willar, 2015: 193).

Talking about quality is not a simple and easy matter, because the quality is abstract. Tjiptono \& Diana (1995: 2) explain the concept of quality itself is often regarded as a measure of the relative goodness of a product consisting of design quality and quality of suitability. actually is an interesting topic in

the development of a college. Quality improvement is actually a problem that is closely related to policies, commitments, and priorities of the development of higher education institutions. Edward Sallis (2012: 52) explains that quality is a standard to show the quality of excellence of something. In the college quality complex, quality itself will be considered when able to 1) meet the needs of the community; 2) presenting figures who are able to contribute positively to their development; 3) printing people needed in the world of work; 4) giving birth to creative people; 5) productive and high innovation in clearing jobs, and 6) giving birth to professionals in developing their knowledge in accordance with their qualifications (Mulyono Agus, et al., 2007: ix). Quality means the degree of superiority of a product in the form of goods or services. Oakland (1993: 5) states that quality is used to show the superiority of a product or service. The quality concept according to Tilaar (2012: 36) that quality has many meanings such as the degree of action, according to requirements, overall satisfying characteristics in product use. Macdonald (1993: 6) states that quality means compliance with requirements. Requirements that make it possible to measure quality by knowing that something meets certain conditions to be said to be of quality. Therefore, improving the quality of higher education, the authors want to say that it is not a product that is easy and requires a long process because the main ones are needed, are: 1) a truly complete plan, and 2) a high commitment to achieving a vision, mission, and purpose.

Internal audit/monitoring and evaluation policies depend on Higher Education policies. The internal audit/monitoring team is determined based on the institutional procedures listed in the Quality Policy document which must be included in the academic calendar two weeks earlier.

The quality assurance approach means that the process is interrelated, and integrated to make the whole. The implementation of academic quality assurance at IAIN Ambon is detailed in the Quality Manual. 1) Details of activities carried out at the AMAI opening meeting. 2) Inspection of the field. If there are indications that lead to recording nonconformities, even if they are not included in the checklist and further investigated, the results of the interview must be tested by seeking information about the same from other independent sources.

Republic of Indonesia Law Number 12 of 2012 concerning Higher Education article 53 states that the internal quality assurance system developed by higher education covers 10 standards, namely standards: content, process, competency of graduates, educators and education staff, facilities and infrastructure, management, financing, assessment, research, and community service.

According to I Gusti Ngurah Triyana (2017: 120) explained that every college can develop its own SPMI in accordance with the historical background, the basic value that animates the establishment of the college, the number of study programs and human resources, the university's facilities and infrastructure without interference from other parties. Furthermore, an explanation from I Gusti Ngurah Triyana (2017: 120) that even though every college can develop SPMI independently, there are basic things that must be in the SPMI of each college. Therefore, to analyze the urgency of the internal academic quality audit policy the author starts from the concept of quality, the urgency of the author's internal academic quality audit means more into the benefits of SPMI, because, there are several benefits of internal academic quality policy audiences, for guaranteeing quality standards: 1) education; 2) research, and 3) community service. These three concepts are interesting to explore further. Because in essence is a part that cannot be separated in improving the quality of higher education.

Expected quality achievement efforts certainly are inseparable from leadership support and good managerial processes to improve the work ethic of the academic community in order to create a conducive academic environment. Managerial ability is an important and strategic factor in the framework of improving the quality and progress of the universities they lead.

Responsible university leaders must be aware that the development and improvement of the quality of organizational management are very important. Therefore, to be able to disclose periodic and regular performance, results and impacts of tertiary institutions, an evaluation must be carried out as part of the pattern of higher education management (Ernawati and Hilwati, 200: 40)

Through the internal quality audit process, it must ensure that the study program has assessment standards, assessment techniques and instruments, assessment mechanisms and procedures up to assessment reports so that through the results of internal quality audits, the standard of this process will continue to increase.

In the scope of higher education, education personnel who have the qualifications as educators are referred to as lecturers, while other education personnel is referred to as supporting staff for education. Lecturers who have fulfilled academic and professional qualifications will be submitted as permanent lecturers, while if needed, the study program will utilize non-permanent lecturers to meet the academic program's quality assurance needs. In this case, SPMI will ensure that the study program has a selection system, development system, retention system and dismissal of lecturers and education staff referring to Minister of Education and Culture No. 49 of 2014 concerning the 
standards of lecturers and education staff.

In order to fulfill the achievement of graduate learning, the standard of facilities and infrastructure has an important role to support the needs of the teaching and learning process. SPMI must ensure that the standards of facilities and infrastructure prepared by universities are in accordance with Permendikbud No. 49 of 2014. Through SPMI, the standards of educational facilities and infrastructure will continue to be evaluated so that they are always adequate, of good quality, easily accessible and used at all times and always experiencing developments to meet the needs of the academic community.

\section{CONCLUSION}

One indicator of the success of university quality is the satisfaction of internal stakeholders. From the description above shows that the internal academic quality audit policy in higher education is very important in improving the quality so that it can produce graduates that are in accordance with what the stakeholders expect. The important value of an effort from the internal quality assurance system if the findings obtained are followed up by program planners and implementers for future improvements. Internal academic quality audits are made as a basis for controlling the management of quality higher education with National standards and complying with government regulations of the Republic of Indonesia. The SPMI process is inseparable from the quality policy, quality objectives of education implementation, and all quality documents that must be disseminated to all academics and leaders of institutions so that they are implemented optimally.

\section{REFERENCES}

Beck, U, (2000). What is Globalization? Cambridge. Polity Press.

Effendi, Sofian. (2002). Revitalizing Higher Education for Sustainaiunable Economic Growth, Paper read at Indonesia-German Symposium 2002. Aachen. RWTH, July 29, 2002

Jarvis, Peter. (2001). Universities and Corporate Universities:The Higher Learning Industries in Globalization,London Kogan page Industies,

Kadiman, Kuemayanto, (2002). Tantangan dan Kendala Yang DihadapiITB Sebagai BHMN, Makalah dibacakan pada seminar Nasional Majelis Rektor Wilayah Barat. Bandung. Institut Teknologi Bandung.

Renner, K. Edward, (1995). The New Agenda For Higher Education, Calgary. Detselig Enterprises, Ltd.

Abidin, A. A. (2017). Manajemen Pembiayaan Pendidiakan Tinggi Dalam Upaya Peningkatan Mutu (Studi Kasus Pada Perguruan Tinggi Swasta Menengah di Surabaya). Jurnal Penjaminan Mutu, 3(1), 87-99.
Adina, Bloom Lewkowicz. (2007). Teaching Emotional Intelligence, Strategies and Activities for Helping Student make Effective Choices. California: Corwin Press.

Alba Cecep. (2011). Strategi Peningkatan Mutu Pendidikan Di Perguruan Tinggi.Jurnal Sosioteknologi Edisi 24 Tahun 10, h. 1184-1190.

Fitrah, M. (2017). Peran Kepala Sekolah dalam Meningkatkan Mutu Pendidikan. Jurnal Penjaminan Mutu, 3(1), 31-42.

Jackson, N. (1998). Understanding Standard Based Qualitative Assurance Part 2, Nuts And Bolts Of Dearing Policy Work.

Sallis Edward. (2012). Total Quality Management In Education: Manajemen Mutu Pendidikan. Yogjakarta: Ircisod

Ernawati \& Hilwati. (2001). Pengembangan Mutu Perguruan Tinggi Dengan Pola Manajemen Terpadu.Makalah Lokakarya Asistensi Penyusunan Statuta PTS di Lingkungan Kopertis Wilayah IV, di Bandung, 25 November 2000.

Mulyono Agus, dkk. (2007). Implementasi Sistem Manajemen Mutu UIN Maliki Malang. Malang: LPM UIN Malang.

Olssen, Mark. (2004). Education Policy: Globalization, Citizenship and Democracy. London: Sage Publications.

Wicaksono Galih Wasis\& Al-Rizki Andi.(2016). Peningkatan Kualitas Evaluasi Mutu Akademik Universitas Muhammadiyah Malang melalui Sistem Informasi Mutu.Kinetik, Vol.1, No.1, hal.1-8 